\title{
Penerapan Pembelajaran Kooperatif Tipe Index Card Match untuk Meningkatkan Aktivitas dan Hasil Belajar Biologi Kelas VII SMP Negeri 4 Narmada Tahun Pelajaran 2010/2011
}

\author{
Arif Budiman \\ SMP Negeri 4 Narmada, Lombok Barat, Indonesia \\ *Coresponding Author: arifbud@gmail.com
}

\begin{abstract}
Abstrak: Masalah yangg dihadapi oleh guru IPA Biologi di SMP Negeri 4 Narmada adalah kesulitan siswa dalaam memahami materi yangg diberikan dengn menggunakan model pembelaajaran yangg belum mengaktifkan seluruh siswa. Selama ini guru masih menggunakan model pembelaajaran kelompok yangg konvensional. Model pembelaajaran seperti ini menyebabkan kurangnya keterlibatan seluruh siswa dalaam proses belajar mengajar. Tujuan penelitian adalah untuuk mengetahui penerapan pembelaajaran koperatif tipe Index Card Match dalaam meningkatkan aktivitas dan hasil belajar biologi kelas VII SMP Negeri 4 Narmada. Jenis penelitian ini adalah Penelitian Tindakan Kelas (PTK) yangg dilaksanakan dalaam 2 siklus dan masing-masing siklus terdiri atas perencanaan, pelaksanaan, observasi, dan refleksi. Ada dua jenis data yangg digunakan dalaam penelitian ini yaitu kuantitatif berupa hasil tes dan data kualitatif berupa lembar observasi. Teknik analisis data yangg digunakan adalah rumus ketuntasan klasikal (KK). Berdasarkan Hasil penelitian menunjukkan adanya peningkatan aktivitas belajar siswa dari kategori cukup aktif pada siklus I menjadi sangat aktif pada siklus II. Sementara persentase ketuntasan belajar siswa pada siklus I sebesar 62,6\% dan pada siklus II meningkat menjadi $88,5 \%$. Berdasarkan hasil penelitian tersebut dapat disimpulkan bahwa penerapan metode Index Card Match dapat meningkatkan aktivitas dan hasil belajar biologi kelas VII SMP Negeri 4 Narmada Tahun pelajaran 2010/2011.
\end{abstract}

Kata Kunci: Pembelajaran Koperatif, Bamboo Dancing, Besaran dan Satuan

\section{PENDAHULUAN}

Dalaam kehidupan suatu negara, pendidikan memegang peranan yangg amat penting untuuk menjamin kelangsungan hidup negara dan bangsa, karena dengn adanya pendidikan dapat meningkatkan dan mengembangkan kualitas Sumber Daya Manusia (SDM). Pendidikan merupakan sarana untuuk menyiapkan generasi masa kini dan sekaligus masa depan. Hal ini berarti bahwa proses pendidikan yangg dilakukan pada saat ini bukan semata-mata untuuk hari ini, melainkan untuuk masa depan. Salah satu upaya untuuk meningkatkan mutu pendidikan adalah dengn cara memperbaiki proses belajar mengajar.

Belajar mengajar pada dasarnya adalah interaksi atau hubungan timbal balik antara guru dan siswa dalaam situasi pendidikan yangg melibatkan berbagai macam aktivitas yangg harus dilakukan, terutama jika menginginkan hasil belajar. Oleh karena itu, guru dalaam mengajar dituntut kesabaran, keuletan dan sikap terbuka disamping kemampuan dalaam situasi belajar mengajar yangg lebih aktif. Guru dapat memilih dan menggunakan model pembelaajaran yangg tepat karena pemilihan model pembelaajaran yangg tepat pada hakikatnya merupakan salah satu upaya dalaam mengoptimalkan hasil belajar siswa.

Dalaam proses belajar mengajar melibatkan berbagai macam aktivitas yangg harus dilakukan, terutama jika menginginkan hasil belajar yangg optimal. Salah satu cara yangg dapat dipakai agar mendapatkan hasil yangg optimal seperti yangg diinginkan adalah memberi tekanan dalaam proses pembelaajaran. Hal ini dapat 
dilaksanakan dengn memilih salah satu model pembelaajaran yangg tepat karena pemilihan model pembelaajaran yangg tepat pada hakikatnya merupakan salah satu upaya dalaam mengoptimalkan hasil belajar siswa.

Hasil belajar yangg baik adalah sesuatu yangg selalu diharapkan oleh seorang guru, namun kenyataannya bahwa hasil rata-rata belajar siswa pada mata pelajaran biologi belum sesuai dengn yangg diharapkan. Demikian halnya di SMP Negeri 4 Narmada, khususnya kelas VII yangg hasil belajar Biologi masih sangat rendah.

Hal ini bisa dilihat dari hasil observasi dan wawancara yangg dilakukan oleh peneliti dengn guru Biologi Kelas VII SMP Negeri 4 Narmada pada tabel di bawah berikut :

Tabel 1. Nilai Ketuntasan Klasikal Hasil Belajar Siswa Kelas VII SMPN 4 Narmada Semester 1 Tahun pelajaran 2010/2011.

\begin{tabular}{|c|c|c|c|c|}
\hline No & Kelas & $\begin{array}{c}\text { Jumlah } \\
\text { Siswa }\end{array}$ & $\begin{array}{c}\text { Siswa yangg } \\
\text { tuntas }\end{array}$ & $\begin{array}{c}\text { Ketuntasan } \\
\text { klasikal \% }\end{array}$ \\
\hline 1 & VII A & 29 & 29 & 100 \\
\hline 2 & VII B & 29 & 25 & 86 \\
\hline 3 & VII C & 29 & 28 & 96 \\
\hline 4 & VII D & 24 & 17 & 71 \\
\hline 5 & VII E & 28 & 24 & 85 \\
\hline
\end{tabular}

Dari Tabel 1.1 di atas dapat diperhatikan bahwa hasil belajar siswa belum tuntas, suatu kelas dikatakan tuntas apabila $\geq 85 \%$ siswa mencapai ketuntasan individu, oleh karena itu nilai ketuntasan klasikal siswa itu tidak menunjukan ketuntasan belajar.

Nilai ketuntasan klasikal siswa kelas VII SMPN 4 Narmada semester 1 Tahun Pelajaran 2010/2011 ada satu kelas yangg menunjukan ketidaktuntasan nilainya yaitu kelas kelas VIID karena nilai siswa itu dikatakan tuntas apabila nilainya sudah tercapai atau terlampaui dan ada empat kelas yangg menunjukan hasil ketuntasan nilainya yaitu kelas VIIA, VIIB, VIIC dan VIIE karena nilai dari empat kelas ini sudah mencapai $85 \%$ ke atas.

Dengn mengetahui masalah pokok yangg menjadi kendala dalaam pembelaajaran Biologi terutama pada siswa kelas VII SMPN 4 Narmada adalah kesulitan belajar siswa, aktivitas belajar siswa dan hasil belajar siswa rendah. Hal ini disebabkan strategi atau metode pembelaajaran yangg diterapkan oleh guru tersebut dalaam proses pembelaajaran kurang menyenangkan dan kurangnya kesadaran siswa akan pembelaajaran Biologi. Selama ini guru masih menggunakan model pembelaajaran kelompok yangg konvensional. Model pembelaajaran seperti ini menyebabkan keterlibatan seluruh siswa dalaam aktivitas pembelaajaran sangat kecil, karena kegiatan pembelaajaran didominasi oleh siswa yangg memiliki kemampuan tinggi sementara yangg memiliki kemampuan rendah hanya menonton saja (pasif). Hal ini berarti dalaam suatu kelompok belajar masih banyak siswa yangg tidak melakukan keterampilan koperatif. Hal ini yangg menyebabkan sebagian besar siswa terutama yangg memiliki kemampuan rendah enggan berpikir, sehingga timbul perasaan jenuh dan bosan dalaam mengikuti pelajaran biologi. Akibat dari sikap siswa tersebut, maka hasil belajarnyapun kurang memuaskan, dalaam arti tidak memenuhi batas ketuntasan yangg ditetapkan sekolah. 
Menyikapi masalah tersebut di atas, memungkinkan suatu metode pembelaajaran yangg dapat mengatasi permasalahan siswa yaitu dengn menerapkan metode pembelaajaran tipe Index Card Match (mencari pasangan kartu) diberikan pada pembelaajaran biologi, karena pada pembelaajaran biologi, aktivitas belajar siswa dan motivasi belajar siswa masih kurang yangg akhirnya dapat mempengaruhi hasil belajar siswa. Dengn menerapkan metode pembelaajaran koperatif tipe Index Card Match diharapkan dapat meningkatkan aktivitas belajar dan hasil belajar siswa. melalui penerapan ini juga dapat memudahkan guru untuuk memperbaiki cara berfikir, keterampilan berkomunikasi dengn siswa dan meningkatkan keterlibatan siswa di dalaam Proses Belajar Mangajar (PBM). Jadi, materi yangg dipelajari siswa akan melekat untuuk periode waktu yangg lama. Model pembelaajaran koperatif tipe index card match cocok digunakan di SMP mengingat kondisi siswa SMP yangg dalaam keadaan proses belajar mengajar (PBM) menyukai belajar sambil bermain yangg bisa membuat mereka menemukan hal baru dan mereka juga lebih terbuka dengn teman sebaya dalaam memecahkan permasalahan yangg mereka hadapi.

Dari permasalahan yangg telah diuraikan di atas, penulis bermaksud mengadakan penelitian dengn judul: "Penerapan Pembelaajaran Koperatif Tipe Index Card Match untuuk Meningkatkan Aktivitas dan Hasil Belajar Biologi Siswa Kelas VII SMPN 4 Narmada Tahun Pelajaran 2010/2011.

\section{KAJIAN TEORI}

\section{Belajar dan pembelaajaran}

Menurut teori behavioristik belajar adalah perubahan tingkah laku sebagai akibat dari adanya interaksi antara stimulus dan respon. Atau dengn kata lain, belajar merupakan bentuk perubahan yangg dialami siswa dalaam hal kemampuannya untuuk bertingkah laku dengn cara yangg baru sebagai hasil antara stimulus dan respon. Dimana stimulus adalah berupa apa saja yangg diberikan guru kepada siswa misalnya: alat peraga, pedoman kerja, atau cara-cara tertentu untuuk membantu belajar siswa, sedangkan respons adalah reaksi atau tanggapan siswa terhadap stimulus yangg diberikan oleh guru tersebut (Budiningsih, 2004)

Menurut pengertian secara psikologis, belajar merupakan suatu proses perubahan yaitu perubahan tingkah laku sebagai hasil dari interaksi dengn lingkungannya dalaam memenuhi kebutuhan hidupnya. Perubahan-perubahan tersebut akan nyata dalaam seluruh aspek tingkah laku. Jadi belajar ialah suatu proses usaha yangg dilakukan seseorang untuuk memperoleh suatu perubahan tingkah laku yangg baru secara keseluruhan, sebagai hasil pengalamannya sendiri dalaam interaksi dengn lingkungannya (Slameto, 2010).

\section{Pembelaajaran Koperatif}

Menurut Dzaki (2009), pembelaajaran koperatif merupakan suatu model pengajaran dimana siswa belajar dalaam kelompok kelompok kecil yangg memiliki tingkat kemampuan berbeda. Dalaam menyelesaikan tugas kelompok, setiap anggota saling kerjasama dan membantu untuuk memahami suatu bahan pembelaajaran. Vygotsky dalaam Suprijono (2009), menekankan peserta didik mengonstruksikan pengetahuan melalui interaksi soisal dengn orang lain. 
Pembelaajaran koperatif adalah konsep yangg lebih luas meliputi semua jenis kerja kelompok termasuk bentuk-bentuk yangg lebih dipimpin oleh guru atau diarahkan oleh guru. Secara umum pembelaajaran koperatif dianggap lebih diarahkan oleh guru, dimana guru menetapkan tugas pertanyaan-pertanyaan serta menyediakan bahan-bahan dan informasi yangg dirancang untuuk membantu peserta didik menyelesaikan masalah yangg dimaksud. Guru biasanya menetapkan bentuk ujian tertentu pada akhir tugas (Suprijono, 2009)

Roger dan David Jhonson dalaam Suprijono (2009), menyatakan bahwa tidak semua belajar kelompok bisa dianggap pembelaajaran koperatif. Untuuk mencapai hasil yangg maksimal, lima unsur dalaam model pembelaajaran koperatif harus diterapkan yaitu antara lain :

a. Positive interdependence (saling ketergantungan positif)

Unsur ini menunjukkan bahwa dalaam pembelaajaran koperatif ada dua pertanggung jawaban kelompok.

1). mempelajari bahan yangg ditugaskan kepada kelompok

2). menjamin semua anggota kelompok secara inddividu mempelajari bahan yangg ditugaskan tersebut.

b. Personal responsibility (tanggung jawab perseorangan).

Tanggung jawab perseorangan adalah kunci untuuk menjamin semua anggota yangg diperkuat oleh kegiatan belajar bersama. Artinya, setelah mengikuti kelompok kerja bersama, anggota kelompok harus dapat menyelesaikan tugas yangg sama.

c. Face to face promotive interaction (interaksi promotif) ciri-ciri interaksi promotif adalah :

1). saling membantu secara efektif dan efisien.

2). saling memberi informasi dan sarana yangg diperlukan.

3). memproses informasi bersama secara lebih efektif dan efisien.

4). saling mengingatkan.

5). saling membantu dalaam merumuskan dan mengembangkan. argumentasi serta meningkatkan kemampuan wawasan terhadap masalah yangg dihadapi.

6). saling percaya.

7). saling memotivasi untuuk memperoleh keberhasilan bersama.

d. Interpersonal skill (komunikasi antar anggota)

Untuuk mengkoordinasikan kegiatan pesrta didik dalaam pencapaian tujuan peserta didik harus :

1). saling mengenal dan mepercayai.

2). mampu berkomunikasi secara akurat dan tidak ambisius.

3). saling menerima dan saling mendukung.

4). mampu menyelesaikan konflik secara konstruktif.

e. Group processing (Proses kelompok)

Proses mengandung arti menilai. Melalui proses kelompok dapat diidentifikasi dari urutan atau tahapan kegiatan kelompok dan kegiatan dari anggota kelompok. Siapa diantara anggota kelompok yangg sangat membantu dan siapa yangg tidak membantu. Tujuan proses kelompok adalah untuuk meningkatkan efektifitas anggota dalaam memberikan kontribusi terhadap kegiatan kolaboratif untuuk mencapai tujuan kelompok. 


\section{Metode pembelaajaran Index Card Match}

Metode Index Card Match dikenal juga dengn istilah "mencari pasangan kartu". Metode ini berpotensi membuat siswa senang. Unsur permainan yangg terkandung dalaam metode ini tentunya membuat pembelaajaran tidak membosankan. Tentu saja penjelasan aturan permaian perlu diberikan kepada siswa agar metode ini menjadi lebih efektif. Metode ini sangat tepat untuuk mengulangi materi pembelaajaran yangg telah diberikan sebelumnya. Adapun langkah-langkah pembelaajaran dengn metode ini adalah sebagai berikut :

a. Guru mempersiapakan potongan-potongan kertas sebanyak jumlah siswa yangg ada di dalaam kelas.

b. Potongan-potongan kertas tersebut dibagi lagi menjadi dua bagian yangg sama.

c. Pada separuh bagian ditulis pertanyaan tentang materi yangg dibelajarkan. Setiap kertas berisi satu pertanyaan.

d. Pada separuh bagian yangg lain, ditulis jawaban dari pertanyaan-pertanyaan yangg telah dibuat.

e. Kemudian potongan-potongan tersebut dicampur aduk secara acak, sehingga tercampur antara soal dengn jawaban.

f. Kertas-kertas tersebut kemudian dibagikan kepada setiap siswa, satu siswa satu kertas. Diterangkan aturan main bahwa siswa yangg mendapat soal harus mencari temannya yangg mendapat jawaban dari soal yangg diperolehnya, demikian pula sebaliknya.

g. Setelah siswa menemukan pasanganya, siswa diminta untuuk duduk sesuai dengn pasangan yangg diperolehnya. Antar pasangan satu dengn yangg lain diminta untuuk tidak memberitahukan materi yangg diperolehnya.

h. Setelah semua siswa menemukan pasangannya dan duduk berdekatan, setiap pasangan diminta untuuk membacakan soal yangg diperoleh dengn suara keras secara bergantian agar didengar oleh teman-teman yangg lain, kemudian pasangannya membacakan jawaban juga dengn suara keras.

i. Setelah semua pasangan telah membaca soal dan jawaban yangg diperoleh kemudian guru membuat klarifikasi. Bersama-sama siswa guru membuat kesimpulan hasil belajar yangg telah dilakukan.

Metode ini cukup menarik untuuk diterapkan, selain ada unsur permainan kebersamaan dan membangun keakraban antar siswa yangg satu dengn yangg lain. Metode ini juga dapat digunakan untuuk mengetahui tingkat pemahaman siswa terhadap materi pelajaran yangg telah diberikan guru kepada siswanya.

\section{Aktivitas Belajar}

Aktivitas belajar merupakan seluruh kegiatan siswa dalaam proses belajar mengajar. pada prinsipnya belajar adalah berbuat, tidak ada belajar jika tidak ada aktivitas. Itulah mengapa aktivitas merupakan prinsip yangg sangat penting dalaam interaksi belajar mengajar (Sardiman, 2001).

Menurut Hamalik (2010), aktivitas adalah belajar yangg menyediakan kesempatan untuuk belajar sendiri atau melakukan aktivitas sendiri. Aktivitas masing-masing siswa dalaam pembelaajaran tentulah tidak sama. Hal ini banyak dipengaruhi kegiatan mengajar guru, salah satu ciri pengajaran yangg dapat dilihat dari kadar aktivitas belajar makin tinggi aktivitas belajar siswa makin tinggi peluang 
berhasilannya pengajaran ini berarti kegiatan guru mengajar harus merangsang aktivitas siswa melakukan berbagai aktivitas belajar (Sudjana, 2005).

Kegiatan belajar / aktivitas belajar sebagai proses terdiri atas enam unsur yaitu tujuan belajar, peserta didik yangg termotivasi, tingkat kesulitan belajar, stimulus dari lingkungan, pesrta didik yangg memahami situasi, dan pola respons peserta didik (Sudjana, 2005).

Paul B. Diedrich dalaam Hamalik (2010), membagi kegiatan belajar dalaam 8 kelompok yaitu :

1). Kegiatan-kegiatan visual seperti membaca, melihat gambar-gambar, mengamati eksperimen, demonstrasi, percobaan, pameran dan orang lain bekerja atau bermain.

2). Kegiatan-kegiatan lisan (oral) mengemukakan suatu fakta atau prinsip, menghubungkan suatu kejadian, mengajukan pertanyaan, memberi saran, mengemukakan pendapat, wawancara, diskusi, interupsi dan sebagainya.

3). Kegiatan-kegiatan mendengarkan seperti mendengarkan penyajian bahan, mendengarkan percakapan atau diskusi kelompok, mendengarkan suatu permainan, mendengarkan radio, pidato dan sebagainya.

4). Kegiatan-kegiatan menulis seperti menulis cerita, memeriksa karangan, menulis laporan, bahan-bahan copy, mengerjakan tes, membuat rangkuman dan mengisi ang angket.

5). Kegiatan-kegiatan menggambar seperti menggambar, membuat grafik, peta diagram, pola, dan sebagainya.

6). Kegiatan metric seperti melakukan percobaan, memilih alat-alat, mengadakan pameran, membuat model, menyelenggarakan permainan, menari dan berkebun.

7). Kegiatan-kegiatan mental seperti merenungkan, mengingat, memecahkan masalah, menganalisis, factor-faktor, melihat, hubungan-hubungan dan membuat keputsan.

8). Kegiatan-kegiatan emosional seperti menaruh minat, membedakan, berani, gembira, tenang, gugup dan sebagainya.

\section{Hasil Belajar}

Hasil belajar adalah perubahan tingkah laku yangg mencakup bidang kognitif, afektif, dan psikomotorik. Melalui proses belajar seseorang akan mengalami perubahan dalaam tingkah lakunya yakni sebagai hasil belajar yangg dilakukannya. Proses belajar mengajar dan hasil belajar merupakan dua hal yangg tidak dapat dipisahkan. Untuuk itu, maka segala sesuatu yangg mempengaruhi proses belajar harus dioptimalkan agar mencapai hasil belajar yangg lebih baik (Suprijono, 2009).

Menurut Bloom dalaam Suprijono (2009), ada tiga kemampuan yangg diharapkan siswa sebagai hasil belajar yaitu :

1. Kognitif Domain, yaitu perilaku yangg berhubungan dengn pengetahuan, ingatan, pemahaman, menjelaskan, menguraikan, merencanakan, menilai dan menerapkan.

2. Afektif Domain, yaitu perilaku yangg berhubungan dengn sikap menerima, memberikan respons, menilai, organisasi dan karakteristik.

3. Psikomotor Domain, yaitu perilaku yangg berhubungan dengn keterampilan atau skill yangg berkaitan dengn fisik.

Sedangkan menurut Gagne dalaam Suprijono (2009), hasil belajar berupa: 
a. Informasi verbal yaitu kapabilitas kemampuan mengungkapkan pengetahuan dalaam bentuk bahasa, baik lisan maupun tulisan. Kemampuan merespon secara spesifik terhadap rangsangan spesifik. Kemampuan tersebut tidak memerlukan manipulasi simbol, pemecahan masalah maupun penerapan aturan.

b. Keterampilan intelektual yaitu kemampuan mempresentasikan kemampuan dan lambang. Keterampilan intelektual terdir dari kemampuan menginterogasi, kemampuan analitis-sintesis fakta-konsep dan mengembangkan prinsip-prinsip keilmuan. Keterampilan intelektual merupakan kemampuan melakukan aktifitas kognitif yangg bersifat khas.

c. Strategi kognitif yaitu kecakapan menyalurkan dan mengarahkan aktivitas kognitifnya sendiri. Kemampuan ini meliputi pengunaan konsep dan kaidah dalaam memecahkan masalah.

d. Keterampilan motorik yaitu kemampuan melakukan serangkaian gerak jasmani dalaam urusan dan koordinasi, sehingga terwujud otomatisme gerak jasmani.

e. Sikap adalah kemampuuan menerima atau menolak objek berdasarkan penilaian terhadap objek tersebut. Sikap berupa kemampuan menginternalisasi dan eksternalisasi nilai-nilai. Sikap merupakan kemapuan menjadikan nilai-nilai sebagai standar perilaku.

\section{METODE PENELITIAN}

\section{Jenis Penelitian}

Adapun jenis penelitian yangg digunakan adalah Penelitian Tindakan Kelas (PTK). Penelitian tindakan kelas adalah suatu pencermatan terhadap kegiatan belajar yangg dilakukan oleh guru berupa sebuah tindakan yangg sengaja dimunculkan dan terjadi dalaam sebuah kelas secara bersama dengn tujuan untuuk memperbaiki kinerjanya sebagai guru, sehingga hasil belajar siswa dapat meningkat (Arikunto, 2006).

Penelitian tindakan kelas juga dapat diartikan sebagai suatu kegiatan ilmiah yangg dilakukan oleh guru di kelasnya. Menurut Kemmis dan Mc Taggart (dalaam Kunandar, 2010), penelitian tindakan kelas dilakukan melalui proses yangg dinamis dan komplementari yangg terdiri dari empat "momentum" esensial, yaitu penyusunan rencana, tindakan, observasi dan refleksi.

\section{Pendekatan Penelitian}

Alternatif pendekatan yangg digunakan dalaam penelitian ini adalah kuasi eksperimen (eksperimen semu). Jadi penelitian kuasi eksperimen menggunakan seluruh subjek dalaam kelompok belajar (intact group) untuuk diberi perlakuan (treatment), bukan menggunakan subjek yangg diambil secara acak.

Dalaam penelitian ini data kualitatif memuat data-data berupa aktivitas belajar siswa sedangkan data kuantitatif memuat data-data tentang hasil belajar.

\section{Rancangan Penelitian}

Rancangan penelitian dalaam penelitian ini adalah kegiatan pembelaajaran dengn menggunakan penelitian tindakan kelas (PTK). Menurut Arikunto, (2006), rancangan penelitian merupakan proses penelitian yangg dilakukan secara terencana, 
bertujuan dan sistematis. Dalaam penelitian ini dirancang dua siklus. Setiap siklus terdiri dari empat tahapan yaitu perencanaan, pelaksanaan, evaluasi dan refleksi. Tahapan dari masing-masing siklus adalah sebagai berikut :

\section{a. Tahap Perencanaan Tindakan} berikut:

Kegiatan-kegiatan dalaam perencanaan tindakan penelitian ini sebagai

a. Menyusun program satuan pelajaran

b. Menyusun rencana pengajaran

c. Menyusun instrument penelitian yangg meliputi : pedoman observasi beserta lembar observasi untuuk mengamati aktivitas siswa maupun guru dalaam proses belajar mengajar dan instrument asesmen untuuk mengukur hasil belajar siswa.

1). Soal tes digunakan sebagai alat evaluasi

2). Lembar observasi digunakan untuuk mengetahui tingkat aktivitas siswa selama pembelaajaran berlangsung

\section{b. Tahap Pelaksanaan Tindakan}

Pelaksanaan pembelaajaran disesuaikan dengn jadwal mata pelajaran biologi di sekolah tersebut. Adapun pelaksanaan tindakan siklus I adalah melaksanakan pembelaajaran yangg telah direncanakan dalaam skenario pembelaajaran pada siklus I dan mengenai kejadian atau hal-hal yangg terjadi selama proses belajar mengajar sebaiknya didokumentasikan melalui pengamat atau guru itu sendiri dalaam bentuk data hasil pengamatan dengn mengacu pada pedoman observasi aktivitas siswa maupun pedoman observasi aktivitas guru yangg sudah ditetapkan dan sudah disepakati oleh guru dan observer pada siklus I.

\section{c. Tahap Observasi Dan Evaluasi}

Pada tahap ini dilaksanakan observasi terhadap pelaksanaan tindakan. Observasi dilakukan selama proses pembelaajaran sedangkan evaluasi dilakukan terhadap hasil belajar setiap akhir siklus. Hal-hal yangg diobservasi dan evaluasi adalah sebagai berikut:

1. Observasi aktivitas belajar siswa dalaam proses pembelaajaran di kelas.

2. Mengevaluasi hasil test. Hasil belajar siswa pada tindakan pertama dilihat dari hasil test yangg telah diberikan pada akhir pembelaajaran.

\section{d. Refleksi.}

Refleksi meliputi kegiatan analisis, sintesis, penafsiran, menjelaskan dan menyimpulkan. Pada siklus ini guru dan pengamat (observer) mendiskusikan hasil observasi mengenai kejadian-kejadian selama mengajar apakah sudah sesuai dengn kesepakatan pada siklus I dengn berpatokan pada pedoman observasi aktivitas siswa dan guru dalaam proses pembelaajaran. Dalaam fase keempat ini mungkin ditemukan hal-hal yangg belum baik sehingga diperlukan perlakuan ulang guna perbaikan proses pembelaajaran yangg sudah dilaksanakan sebelumnya. Bila demikian dapat dilakukan penelitian putaran kedua (Siklus II) yangg menekankan langkah-langkah perbaikan pada siklus I.

Pelaksanaan tindakan pada siklus II sama seperti siklus I tetapi merupakan perbaikan terhadap kendala-kendala yangg muncul pada siklus I. Jika pada siklus II belum tuntas, maka di lanjutkan lagi ke siklus III dengn tahapan yangg sama. 


\section{Subjek Penelitian}

Arikunto (2007), menyatakan bahwa dalaam PTK tidak ada istilah populasi dan sampel, namun yangg ada adalah setting penelitian yangg berisi tentang subjek penelitian dan fokus penelitian.

Subjek dalaam penelitian adalah siswa kelas VIID SMP Negeri 4 Narmada Lombok Barat yangg berjumlah 24 orang dengn komposisi perempuan 12 siswa dan laki-laki 12 siswa.

\section{Teknik Pengumpulan Data}

Teknik pengumpulan data dalaam hal ini adalah:

1. Data tentang aktivitas belajar siswa dalaam Proses Belajar Mengajar (PBM) diambil lewat lembar observasi yangg dilakukan pada setiap siklus.

2. Data mengenai hasil belajar siswa diperoleh dengn cara memberikan tes hasil evaluasi belajar pada siswa tiap akhir siklus dengn bentuk soal tes objektif (pilihan ganda). Siswa diberi tes hasil belajar yangg diadakan secara individual dengn tujuan untuuk mengetahui peningkatan hasil belajar siswa pada tiap siklus.

\section{Instrumen Penelitian}

Instrumen adalah suatu alat yangg digunakan untuuk mengukur fenomena alam maupun sosial yangg diamati (Sugiyono, 2010). Adapun instrumen yangg digunakan dalaam penelitian ini adalah sebagai berikut:

Tabel 2. Hasil Observasi Aktivitas Belajar Siswa Siklus I dan Siklus II

\begin{tabular}{|c|c|c|c|c|c|}
\hline No & Siklus & $\begin{array}{c}\text { Jumlah skor } \\
\text { aktivitas siswa }\end{array}$ & $\begin{array}{c}\text { Skor } \\
\text { maksimal }\end{array}$ & $\begin{array}{c}\text { Persentase } \\
(\%)\end{array}$ & Kategori \\
\hline 1 & I & 24 & 40 & $60 \%$ & Cukup aktif \\
\hline 2 & II & 34 & 40 & $85 \%$ & Sangat aktif \\
\hline
\end{tabular}

\section{Lembar Observasi}

Observasi atau pengamatan adalah teknik penilaian yangg dilakukan dengn menggunakan indera secara langsung. Observasi dilakukan dengn menggunakan pedoman observasi yangg berisi sejumlah indikator perilaku yangg akan diamati. Dalaam kegiatan proses belajar mengajar pada lembar observasi ini termuat sejumlah aktivitas siswa dalaam Proses Belajar Mengajar (PBM), (Suprijono, 2009).

2. Tes

Tes adalah cara yangg dapat dipergunakan atau prosedur yangg perlu ditempuh dalaam rangka pengukuran dan penilaian di bidang pendidikan, yangg berbentuk pemberian tugas atau serangkaian tugas baik berupa pertanyaan-pertanyaan yangg harus dijawab, atau perintah-perintah yangg harus dikerjakan oleh testee, sehingga atas dasar data yangg diperoleh dari hasil pengukuran tersebut dapat dihasilkan nilai yangg melambangkan tingkah laku atau prestasi testee; dimana nilainya dapat dibandingkan dengn nilai-nilai yangg dicapai oleh testee lainnya atau dibandingkan dengn nilai standar tertentu (Sudijono, 2009) 
Tes yangg digunakan dalaam penelitian ini berupa tes objektif (pilihan ganda) dengn jumlah item 20 soal dan sumber belajarnya berupa buku IPA Biologi untuuk SMP Kelas VII.

\section{HASIL DAN PEMBAHASAN}

\section{Hasil Penelitian}

Penelitian tindakan kelas ini dilaksanakan di SMP Negeri 4 Narmada Lombok Barat untuuk mengetahui peningkatan aktivitas dan hasil belajar siswa kelas VIID pada pokok bahasan ekosistem dengn menerapkan metode pembelaajaran koperatif tipe Index Card Match. Penelitian ini dilaksanakan dalaam 2 siklus.

Pengambilan data ini berlangsung dari tanggal 21 Maret sampai tanggal 18 april 2011 yangg dilakukan dalaam 2 siklus, adapun subyek dalaam penelitian ini adalah siswa kelas VIID SMP Negeri 4 Narmada Lombok Barat Tahun Pelajaran 2010/2011 dengn jumlah siswa sebanyak 24 orang. Dalaam penelitian ini ada 2 jenis data yangg diperoleh yaitu data kualitatif dan data kuantitatif. Data kualitatif diperoleh dari hasil observasi aktivitas guru dan siswa dalaam proses belajar mengajar, sedangkan data kuantitatif diperoleh dari hasil evaluasi tes hasil belajar siswa yangg dilaksanakan pada akhir pertemuan tiap siklus untuuk mengetahui prestasi siswa pada materi yangg diberikan. Data tersebut kemudian dianalisis dengn menggunakan rumus yangg telah ditetapkan sebelumnya.

Sebelum melaksanakan kegiatan belajar mengajar pada siklus I, peneliti mempersiapkan hal-hal yangg pokok dalaam pembelaajaran. Adapun rincian pelaksanaan dan hasilnya diuraikan sebagai berikut :

1. Perencanaan adalah

Dalaam merencanakan penelitian maka hal-hal yangg perlu dipersiapkan

a. Menyiapkan rencana pelaksanaan pembelaajaran (RPP) pada pokok bahasan ekosistem.

b. Menyiapkan lembar observasi untuuk mengetahui persentase keterlaksanaan pembelaajaran.

c. Menyiapkan kartu soal dan kartu jawaban pada pokok bahasan ekosistem.

d. Membuat alat evaluasi dalaam bentuk tes pilihan ganda dengn jumlah soal 20 item untuuk melihat hasil belajar siswa.

2. Tindakan

a. Siklus 1

Dalaam tindakan penelitian yangg harus dilakukan adalah pemberian materi dan permasalahan pada hari Senin, 21 Maret 2011. Tindakan berlangsung dengn alokasi waktu $2 \times 40$ menit untuuk pertemuan I dan $2 \times 40$ menit untuuk pertemuan ke-II. Pada akhir penyampaian materi, guru melakukan tanya jawab dengn siswa untuuk mengetahui apakah materi yangg diberikan sudah dimengerti atau dipahami setelah itu siswa melakukan permainan sambil belajar dengn mencari pasangan kartu (Index Card Match) masing-masing kelompok memegang kartu soal dan kartu jawaban sesuai dengn materi yangg diberikan pada hari Senin 21 Maret yangg tujuannya adalah untuuk memantapkan pengetahuan siswa tentang materi yangg sudah diberikan, kemudian guru bersama siswa menarik kesimpulan setelah masing- 
masing kelompok mencocokkan kartu soal dan kartu jawabannya dan pertemuan ke-II berlangsung pada hari Kamis 24 Maret 2011 dengn alokasi waktu 2x40 menit.

Pada akhir siklus guru mengadakan tes evaluasi untuuk siklus 1 selama kurang lebih 80 menit dengn soal 20 item pilihan ganda pada hari Senin 28 Maret 2011.

b. Siklus II

Dalaam tindakan penelitian yangg harus dilakukan adalah pemberian materi dan permasalahan pada hari Kamis 31 Maret 2011. Tindakan berlangsug dengn alokasi waktu 2x40 menit untuuk pertemuan I dan 2x40 menit untuuk pertemuan II. Pada akhir penyampaian materi, guru melakukan tanya jawab dengn siswa untuuk mengetahui apakah materi yangg diberikan sudah dimengerti atau dipahami setelah itu siswa melakukan permainan sambil belajar dengn mencari pasangan kartu (Index Card Match) Masingmasing kelompok memegang kartu soal dan kartu jawaban sesuai dengn materi yangg diberikan pada hari Kamis, 31 Maret 2011 yangg tujuannya adalah untuuk memantapkan pengetahuan siswa tentang materi yangg sudah diberikan, kemudian guru dengn siswa menarik kesimpulan setelah masingmasing kelompok mencocokkan kartu soal dan kartu jawabannya. Sedangkan pertemuan ke-II berlangsung pada hari Senin 11 April 2011 dengn alokasi waktu 2x40 menit.

Pada akhir siklus guru mengadakan tes evaluasi untuuk siklus II selama kurang lebih 80 menit dengn soal 20 item pilihan ganda pada hari Kamis 14 April 2011.

3. Hasil Observasi

Observasi dilakukan pada saat pelaksanaan proses belajar mengajar berlangsung. Data hasil observasi diperoleh dari observer yaitu Karyamuddin S.Pd guru bidang studi biologi di sekolah tersebut dengn mengamati aktivitas guru dan siswa selama proses belajar mengajar berlangsung dengn tujuan supaya peneliti mengetahui kekurangan-kekurangan selama proses kegiatan belajar mengajar yangg nantinya dilakukan refleksi pada siklus-siklus berikutnya.

Adapun hasil observasi aktivitas guru dan siswa sebagai berikut :

a. Hasil Observasi Aktivitas Guru Siklus I dan Siklus II

Berdasarkan hasil observasi aktivitas guru yangg dilakukan dengn mengisi lembar observasi aktivitas guru pada siklus I dan siklus II diperoleh hasil penelitian yangg terlihat pada tabel berikut :

\begin{tabular}{|c|l|c|c|c|c|}
\hline \multirow{2}{*}{ No } & \multicolumn{1}{|c|}{ Aspek } & \multicolumn{2}{c|}{ Siklus I } & \multicolumn{2}{c|}{ Siklus II } \\
\cline { 3 - 6 } & & Pertemuan I & $\begin{array}{c}\text { Pertemu } \\
\text { an II }\end{array}$ & Pertemuan I & $\begin{array}{c}\text { Pertemuan } \\
\text { II }\end{array}$ \\
\hline 1 & Jumlah Indikator & 11 & 11 & 11 & 11 \\
\hline 2 & Kegiatan yangg terlaksana & 24 & 32 & 37 & 43 \\
\hline 3 & Jumlah seluruh kegiatan & 44 & 44 & 44 & 44 \\
\hline 4 & Jumlah persentase (\%) & $54,54 \%$ & $72,72 \%$ & $84,09 \%$ & $97,72 \%$ \\
\hline 5 & Kategori & Cukup aktif & Aktif & Sangat Aktif & Sangat \\
\hline
\end{tabular}




\begin{tabular}{|l|l|l|l|l|l|}
\hline & & & & & Aktif \\
\hline
\end{tabular}

Tabel 3. Hasil Observasi Aktivitas Guru Siklus I dan Siklus II

Berdasarkan tabel di atas diketahui bahwa aktivitas guru pada siklus I pertemuan I dari 11 indikator yangg dinilai, 24 deskriptor yangg nampak dan jumlah seluruh kegiatan adalah 44 . Jika dipersentasekan maka hasilnya adalah $54,54 \%$ dengn kategori cukup aktif.

Sedangkan pada pertemuan II dari 11 indikator yangg dinilai, 32 deskriptor yangg nampak dan 44 adalah jumlah seluruh kegiatan. Jika persentasekan maka hasilnya adalah $72,72 \%$ dengn kategori aktif.

Berdasarkan tabel di atas diketahui bahwa aktivitas guru pada siklus II pertemuan I dari indikator yangg dinilai, 37 deskriptor yangg nampak dan 44 adalah jumlah seluruh kegiatan. Jika persentasekan maka hasilnya adalah 84,09\% dengn kategori Sangat aktif. Sedangkan pada pertemuan II, 43 deskriptor yangg nampak dan 44 adalah jumlah seluruh kegiatan. Jika persentasekan maka hasilnya adalah 97,72\% dengn kategori Sangat aktif.

b. Hasil Observasi Aktivitas Siswa Siklus I dan Siklus II

Hasil observasi yangg dilakukan dengn mengisi lembar observasi aktivitas belajar siswa pada siklus I dan siklus II diperoleh hasil penelitian pada tabel berikut :

Tabel 4. Hasil Observasi Aktivitas Belajar Siswa Siklus I dan Siklus II

\begin{tabular}{|c|l|c|c|}
\hline No & \multicolumn{1}{|c|}{ Aspek } & Siklus I & Siklus II \\
\cline { 2 - 4 } & \multicolumn{1}{|c|}{ Jumlah } & Jumlah \\
\hline 1 & Jumlah indikator & 8 & 8 \\
\hline 2 & $\begin{array}{l}\text { Jumlah skor aktivitas } \\
\text { belajar siswa }\end{array}$ & 24 & 34 \\
\hline 3 & Skor maksimal & 40 & 40 \\
\hline 4 & Jumlah persentase (\%) & $60 \%$ & $85 \%$ \\
\hline 5 & Kategori & Cukup Aktif & Sangat aktif \\
\hline
\end{tabular}

Berdasarkan tabel di atas diketahui bahwa aktivitas belajar siswa pada siklus I memperlihatkan bahwa dari 8 indikator, jumlah skor aktivitas siswa adalah 24. Jika dipersentasekan maka hasilnya adalah $60 \%$ kategori yaitu cukup aktif.

Sedangkan pada siklus II aktivitas belajar siswa memperlihatkan bahwa dari 8 indikator, jumlah skor aktivitas belajar siswa adalah 34. Jika dipersentasekan maka hasil;nya adalah $85 \%$ dengn kategori sangat aktif.

4. Refleksi

Tahap refleksi ini merupakan kegiatan yangg bertujuan untuuk memperbaiki hasil observasi pada siklus sebelumnya. Data hasil observasi dan refleksi disajikan dalaam tabel di bawah ini :

Tabel 5. Data Hasil Observasi Dan Refleksi Tiap Siklus Pembelajran

\begin{tabular}{|l|l|l|}
\hline Siklus & Hasil Observasi & Refleksi \\
\hline & $\begin{array}{c}\text { 1. Guru masih kurang dalaam } \\
\text { penguasaan kelas sehingga }\end{array}$ & $\begin{array}{r}\text { 1. Guru menciptakan suasana kelas yangg } \\
\text { kondusif atau dengn memberi pertanyaan }\end{array}$ \\
\hline
\end{tabular}




\begin{tabular}{|c|c|c|}
\hline & $\begin{array}{l}\text { masih ada siswa yangg } \\
\text { ribut }\end{array}$ & $\begin{array}{l}\text { kepada siswa yg ribut agar antusias siswa } \\
\text { dalaam proses pembelaajaran tercipta. }\end{array}$ \\
\hline \multirow[t]{4}{*}{ Siklus I } & $\begin{array}{l}\text { 2. Interaksi Guru dengn } \\
\text { siswa masih kurang siswa } \\
\text { belum terkendali dengn } \\
\text { baik }\end{array}$ & $\begin{array}{l}\text { 2. Guru mengoptimalkan interaksi antara } \\
\text { siswa dan guru dengn memberikan } \\
\text { sejumlah pertanyaan- pertanyaan yangg } \\
\text { menarik kepada siswa agar interaksi guru } \\
\text { dengn siswa tercipta. }\end{array}$ \\
\hline & $\begin{array}{l}\text { 3. Guru kurang memotivasi } \\
\text { siswa untuuk ikut aktif } \\
\text { dalaam proses belajar } \\
\text { mengajar }\end{array}$ & $\begin{array}{l}\text { 3. Guru harus memberikan motivasi kepada } \\
\text { siswa untuuk membangkitkan minat pada } \\
\text { materi pelajaran yangg diberikan yaitu } \\
\text { dengn memberikan gambaran tentang } \\
\text { kegunaan materi yangg sedang dipelajari } \\
\text { dalaam kehidupan sehari-hari agar } \\
\text { suasana kelas kelihatan hidup. Hal ini } \\
\text { akan berpengaruh terhadap kesiapan dan } \\
\text { konsentrasi siswa, sehingga perhatian } \\
\text { siswa untuuk ikut aktif dalaam proses } \\
\text { belajar mengajar akan menjadi terfokus. }\end{array}$ \\
\hline & $\begin{array}{l}\text { 4. Guru kurang memberi } \\
\text { kesempatan kepada siswa } \\
\text { untuuk bertanya }\end{array}$ & $\begin{array}{l}\text { 4. Guru hendaknya } \\
\text { kesempatan kepada siswa untuuk } \\
\text { bertanya agar supaya dalaam proses } \\
\text { belajar mengajar tidak didominasi oleh } \\
\text { siswa yangg memiliki kemampuan } \\
\text { tinggi. }\end{array}$ \\
\hline & $\begin{array}{l}\text { 5. Guru belum optimal } \\
\text { dalaam memberikan } \\
\text { penguatan (reinforcement) }\end{array}$ & $\begin{array}{l}\text { 5. Guru lebih aktif dalaam memberikan } \\
\text { bimbingan kepada tiap siswa dengn terus } \\
\text { mengoreksi siswa pada tiap pelajaran } \\
\text { berlangsung dengn lebih aktif dan sabar } \\
\text { membimbing siswa yangg mengalami } \\
\text { kesulitan belajar. }\end{array}$ \\
\hline $\begin{array}{l}\text { Siklus } \\
\text { II }\end{array}$ & $\begin{array}{l}\text { Kegiatan pembelaajaran } \\
\text { berjalan dengn baik dan } \\
\text { pengelolaan kelas sudah baik }\end{array}$ & $\begin{array}{l}\text { Lebih di tingkatkan } \\
\text { dan disempurnakan lagi. }\end{array}$ \\
\hline
\end{tabular}

c. Data Hasil Belajar Siswa

Setelah dilaksanakan proses belajar mengajar pada tiap siklus maka siswa diberikan tes evaluasi pada pokok bahasan ekosistem dengn sub pokok bahasan ekosistem dan saling hubungan antara komponen ekosistem. adapun hasilnya disajikan pada tabel dibawah ini:

Hasil evaluasi belajar siswa pada siklus I dan siklus II terlihat pada tabel berikut :

Tabel 6. Hasil Evaluasi Belajar Siswa Kelas VIID Siklus I dan Siklus II

\begin{tabular}{|l|l|c|c|}
\hline No & \multicolumn{1}{|c|}{ Aspek } & Siklus I & Siklus II \\
\hline 1 & Jumlah siswa & 24 & 24 \\
\hline 2 & Jumlah siswa yangg tuntas & 15 & 21 \\
\hline 3 & Jumlah siswa yangg tidak tuntas & 9 & 3 \\
\hline 4 & Persentase ketuntasan klasikal (\%) & $62,6 \%$ & $88,5 \%$ \\
\hline
\end{tabular}




\begin{tabular}{|l|l|c|c|}
\hline 5 & Kriteria ketuntasan & Tidak Tuntas & Tuntas \\
\hline
\end{tabular}

Dari tabel di atas menunjukkan bahwa hasil evaluasi belajar siswa pada siklus I yangg diikuti oleh 24 siswa terdapat 15 siswa yangg tuntas dan 9 siswa yangg tidak tuntas. Jika dipersentasekan ketuntasan secara klasikal sebesar 62,6\%. Sehingga kriteria ketuntasan yaitu tidak tuntas karena masih di bawah $85 \%$.

Sedangkan pada siklus II menunjukkan bahwa hasil evaluasi belajar siswa yangg diikuti oleh 24 siswa terdapat 21 siswa yangg tuntas dan 3 siswa yangg tidak tuntas. Jika dipersentasekan ketuntasan secara klasikal sebesar $88,5 \%$. Sehingga kriteria ketuntasan yaitu tuntas karena di atas $85 \%$.

\section{Pembahasan}

Penelitian tindakan kelas ini dilaksanakan sesuai dengn prosedur penelitian. Diawali dengn perencanaan, pelaksanaan, observasi dan refleksi, penelitian tindakan kelas ini dilaksanakan dalaam 2 siklus kegiatan pembelaajaran.

Berdasarkan Hasil analisis aktivitas guru siklus 1 diketahui bahwa aktivitas guru pada siklus I pertemuan I dari 11 indikator yangg dinilai, 24 kegiatan yangg terlaksana dan jumlah seluruh kegiatan adalah 44 . setelah dipersentasekan hasilnya adalah 54,54\% dengn kategori cukup aktif dan aktivitas guru pertemuan II dari 11 indikator yangg dinilai, 32 kegiatan yangg terlaksana, dan jumlah seluruh kegiatan adalah 44, setelah dipersentasekan hasilnya adalah 72,72\% dengn kategori aktif. Hal ini disebabkan karena adanya beberapa kekurangan-kekurangan yaitu guru masih kurang siap dalaam membuka pelajaran, guru masih kurang dalaam pemberian motivasi dan penyampaian tujuan pembelaajaran, guru masih kurang dalaam pemberian apersepsi kepada siswa, guru masih kurang dalaam penyampaian materi kepada siswa, guru masih kurang dalaam penerapan pembelaajaran koperatif tipe Index Card Match, guru masih kurang mendampingi siswa dalaam kegiatan pembelaajaran, guru masih kurang mampu menciptakan suasana kelas yangg kondusif, guru masih kurang dalaam membimbing siswa untuuk membuat kesimpulan, guru masih kurang pada sasat menutup kegiatan pembelaajaran. Sedangkan pada siklus II pertemuan I aktivitas guru dari 11 indikator yangg dinilai, 37 kegiatan yangg terlaksana dan jumlah seluruh kegiatan adalah 44. setelah dipersentasekan hasilnya adalah 84,09\% dengn kategori sangat aktif dan aktivitas guru siklus II pertemuan II dari 11 indikator yangg dinilai, 43 kegiatan yangg terlaksana, dan jumlah seluruh kegiatan adalah 44, setelah dipersentasekan hasilnya adalah 97,72\% dengn sangat aktif juga. Berdasarkan hasil refleksi terhadap tindakan yangg telah dilakukan pada silkus I. maka dilakukan tindakan pada siklus II., Pada siklus II diadakan penyempurnaan dan perbaikan terhadap kendala-kendala yangg muncul pada siklus I Penyempurnaan dan perbaikan tersebut antara lain Guru bertindak sebagai fasilitator dan meminimalisir perannya yangg dapat membuat siswa terlihat pasif, Guru menciptakan suasana kelas yangg kondusif, sehingga tidak ada lagi siswa yangg mengganggu temannya selama proses pembelaajaran, Memberi pemahaman kepada siswa untuuk tidak mengganggu siswa lain dalaam mencari pasangan kartu karena akan mengganggu konsentrasi temannya yangg lain, Selalu memotivasi siswa untuuk saling bertukar pikiran pada saat mencari pasangan kartu, 
Ketika menyampaikan materi pelajaran guru, guru sedikit memberikan penekanan pada materi-materi yangg dianggap sulit oleh siswa terutama kepada siswa yangg lamban dalaam menerima materi, Menyarankan kepada siswa yangg pandai untuuk tidak mendominasi kelompoknya, namun diberi tugas untuuk membimbing anggota kelompok yangg masih mengalami kesulitan dalaam mencocokkan kartu yangg dipegang.

Berdasarkan hasil observasi aktivitas belajar siswa pada siklus I dalaam kegiatan belajar mengajar menunjukkan peningkatan yangg signifikan pada tiap siklusnya. Siklus I ketercapaian skor aktivitas belajar siswa tergolong kategori cukup aktif dengn persentase $60 \%$. Ketercapaian skor aktivitas belajar siswa pada siklus I ini masih tergolong rendah/kurang sehingga pada siklus selanjutnya perlu ditingkatkan. Hal ini disebabkan oleh kurangnya keterlibatan siswa dalaam proses belajar mengajar, kurangnya antusias siswa dalaam mengikuti pelajaran, kurangnya interaksi siswa dengn guru, kurangnya interaksi siswa dengn siswa lainnya, kurangya kejasama siswa dalaam kelompok, kuragnya aktivitas siswa dalaam melaksanakan proses pembelaajaran, kurangnya partisipasi siswa dalaam menyimpulkan dan merangkum hasil belajar. Sedangkan pada siklus II ketercapaian skor aktivitas belajar siswa mengalami peningkatan dengn persentase $85 \%$ tergolong kategori sangat aktif. Dari hasil analisis pada siklus II terjadi peningkatan aktivitas belajar siswa. Hal ini terjadi karena telah dilakukanya pebaikan-perbaikan terhadap kekurangan yangg terjadi pada siklus I, Berdasarkan hasil refleksi terhadap tindakan yangg telah dilakukan pada silkus I. maka dilakukan tindakan pada siklus II., Pada siklus II diadakan penyempurnaan dan perbaikan terhadap kendala-kendala yangg muncul pada siklus I Penyempurnaan dan perbaikan tersebut antara lain:

Guru harus lebih meningkatkan penguasaan kelas agar tidak ada yangg ribut dan ngobrol di dalaam kelas supaya proses belajar mengajar berlangsung dengn baik, Guru harus memberikan motivasi dengn mengajukan pertanyaan dan materi yangg di bahas sebelumnya untuuk menguji pemahaman siswa dan materi tersebut, Guru harus mengoptimalkan interaksi antara siswa dengn memberikan pertanyaanpertanyaan kepada siswa agar interaksi guru dan siswa tercipta, Guru harus memberikan penguatan atau penghargaan terhadap jawaban atau pertanyaan siswa dengn memberikan poin.

Setelah dilakukan tindakan atau perbaikan yangg ada pada siklus I, maka dilakukan pada siklus II, dalaam usaha perbaikan dan pencapaian proses belajar mengajar yangg lebih baik pada siklus II. Hal ini dapat dilihat pada hasil belajar siswa, dari 24 siswa terdapat 21 siswa yangg tuntas dalaam belajar sedangkan 3 siswa termasuk dalaam kategori tidak tuntas, dengn ketuntasan mencapai 88,5\%.

Bahwa nilai ketuntasan belajar siswa mencapai peningkatan adalah 88,5\%. Hasil ini terjadi karena pada siklus II, siswa sudah dapat memahami prinsip metode yangg digunakan hal ini dapat meningkatkan aktivitas dan hasil belajar siswa. Sedangkan pada siklus 1, siswa masih belum terbiasa dengn metode pembelaajaran yangg diterapkan. Disamping itu juga hasil observasi tentang aktivitas siswa pada siklus II, tergolong aktif, sedangkan aktivitas guru selama proses belajar mengajar berlangsung dengn baik.. Pencapaian ketuntasan belajar pada siklus II. menunjukkan bahwa dengn pembelaajaran koperatif tipe Index Card Match dalaam proses belajar mengajar menyebabkan suasana kelas menjadi hidup dengn partisipasi aktivitas 
siswa dengn kegiatan-kegiatan pembelaajaran yangg dilakukan sehingga pembelaajaran lebih menarik dan menyenangkan dalaam belajar.

Berdasarkan hasil analisis di atas, dapat diketahui bahwa metode Index Card Match dapat meningkatkan aktivitas dan hasil belajar siswa. maka berdasarkan hasil penelitian menunjukan bahwa hipotesis yangg diajukan diterima artinya adanya peningkatan pemahaman belajar dengn Penerapan Pembelaajaran Koperatif Tipe Index Card Match dapat Meningkatan Aktivitas dan Hasil Belajar Biologi Kelas VII SMP Negeri 4 Narmada Tahun Pelajaran 2010/2011.

\section{KESIMPULAN}

Berdasarkan hasil penelitian dan analisa data, dapat ditarik suatu kesimpulan bahwa penerapan pembelaajaran koperatif tipe Index Card Match dapat meningkatkan aktivitas dan hasil belajar biologi siswa kelas VIID SMP Negeri 4 Narmada Tahun Pelajaran 2010/2011. Hal ini dapat dilihat dari peningkatan aktivitas siswa pada siklus I sebesar $60 \%$ dengn kategori cukup aktif dan siklus II sebesar $85 \%$ dengn kategori sangat aktif. Sedangkan untuuk hasil belajar siswa pada siklus I ketuntasan klasikalnya $62,6 \%$ dan siklus II mencapai ketuntasan klasikal sebesar $87.5 \%$.

Berdasarkan kesimpulan yangg diperoleh dari hasil penelitian di atas dapat diberikan beberapa saran yaitu: 1) Mencermati hasil positif penelitian ini maka penerapan metode Index Card Match dapat diterapkan dalaam pembelaajaran biologi pada pokok bahasan ekosistem; 2) Diharapkan kepada guru-guru biologi yangg mempunyai permasalahan sejenis dengn peneliti, agar memanfaatkan hasil penelitian ini sebagai alternatif untuuk bahan pertimbangan dalaam memilih metode belajar; dan 3) Bagi peneliti lanjutan diharapkan dapat melanjutkan tindakan ini dengn menggunakan langkah-langkah pembelaajaran yangg lebih tepat agar siswa lebih giat dalaam belajar.

\section{DAFTAR PUSTAKA}

Arikunto, S. (2006). Prosedur Penelitian Suatu Pendekatan Praktik, Jakarta: PT Rineka Cipta.

Arikunto, S. (2010). Penelitian Tindakan Kelas. : PT Bumi Aksara.

Arikunto, S. (2010). Dasar-dasar Evaluasi Pendidikan. Jakarta : Bumi Aksara.

Budiningsih, A. (2004). Belajar dan Pembelaajaran. Yogyakarta : PT Rineka Cipta.

Dzaki. (2009). http://penelitiantindakankelas.blogspot.com/2009/03/aktivitas-belajarpada-model.html. Diakses tanggal 18 januari 2011.

Handayani. (2009). Penerapan Strategi Belajar Aktif Tipe Index Card Match (ICM) Dalaam Upaya Meningkatkan Aktivitas Dan Hasil Belajar Akuntansi Siswa Di Kelas X Akuntansi 2 SMK Swasta Teladan Medan Tahun Pelajaran 2009/2010.Skripsi.http://juntakmarganagmailcom.blogspot.com/2010/09/penera pan-strategi-belajar-aktif-tipe.html. Diakses tanggal 14 september 2010.

Hamalik, O. (2010). Proses Belajar Mengajar. Jakarta: PT Bumi Aksara.

Kunandar. (2010). Penelitian Tindakan Kelas. Jakarta : PT Rajagrafindo Persada. 
Laela. (2009). Penerapan Strategi Pembelaajaran Index Card Match (mencari pasangan) Untuuk Meningkatkan Hasil Belajar Biologi Pokok Bahasan Fotosintesis Siswa Kelas VIIIG SMP Al-Islam 1 Surakarta Tahun Ajaran 2008/2009. Skripsi. http://etd.eprints.ums.ac.id/4190/1/A420050009.pdf di akses tanggal 18 januari 2011.

Margono, S. (2009). Metodologi Penelitian Pendidikan. Jakarta : Rineka Cipta.

Nurkencana. W. Sunartana. (1999). Evaluasi Hasil Belajar. Surabaya : Usaha Nasional.

Slameto. (2010). Belajar dan Faktor-faktor yangg mempengaruhinya. Jakarta : PT Rineka Cipta.

Sudijono, A. (2009). Pengantar Evaluasi Pendidikan, Jakarta : PT Raja Grafindo persada.

Sudjana, N. (2005). Penelitian Hasil Proses Belajar Mengajar. Bandung: Rosdakarya.

Sugiyono. (2010). Metode Penelitian Pendidikan. Bandung : Alfabeta.

Suprijono, A. (2009). Cooperative Learning. Surabaya : pustaka belajar.

Syamsuri, I. Sulisetijono. Ibrohim. S.E. Rahayu. (2007). Ipa Biologi Untuuk SMP Kelas VII. Malang : Erlangga

Syarifuddin, S. (2018). Pengaruh Pembelaajaran Koperatif Tipe Jigsaw Dan Tipe Group Investigation (GI) Terhadap Ketercapaian Kompetensi Dan Kemampuan Komunikasi Matematika Siswa Di SMA. Jurnal Ilmiah Mandala Education, 4(1), 163-172 